\title{
The Relationship Networks of Entrepreneurs and the Effects of A Formation of An Industry Cluster on Their Relationships
}

\author{
Thor Sigfusson ${ }^{1}$ \\ ${ }^{1}$ Iceland Ocean Cluster and The University of Iceland \\ Correspondence: Thor Sigfusson, Reykjavik Harbour, Ocean Cluster House, Reykjavik Harbour, IS 101 Reykjavik, \\ Iceland. Tel: 354-554-0441. E-mail: thor@sjavarklasinn.is \\ Received: February 21, 2013 \\ Accepted: March 21, 2013 \\ Online Published: March 22, 2013 \\ doi:10.5430/bmr.v2n1p104 \\ URL: http://dx.doi.org/10.5430/bmr.v2n1p104
}

\begin{abstract}
We examine how marine technology entrepreneurs in Iceland build their business network relationships through weak and strong ties and the effects of the formation of an industry cluster on their relationships. This study finds that marine technology entrepreneurs build their network relationships mainly through the formation of strong ties leading to a slow expansion of business relationships. We also find a formation of an industry cluster of marine technology entrepreneurs to enhance the weak ties of the entrepreneurs and their skills in developing these weak relationships. Further, the analytical model we develop shows how factors such as an industry cluster influences the entrepreneurs' relationships.
\end{abstract}

Keywords: Networks, Marine, Relationships, Industry clusters, Entrepreneurship, Empirical study

\section{Introduction}

Iceland's ocean economic zone extends to 0.76 million square $\mathrm{km}$. and encompasses a wealth of natural resources. The Icelandic economy is one of the most seafood dependent economies in the world. The seafood industry has been one of the core industries in Iceland and the country has the highest per capita sea catch in the world. In recent years annual catches have amounted to about 1.7 million metric tonnes annually, some $2 \%$ of the global marine harvest. About $40 \%$ of the country's export earnings have been generated by seafood products.

Another important factor to consider when observing the Icelandic seafood sector is that Icelandic seafood industry has not been sponsored by the Government. The fisheries sector has for the most part been profitable and large and profitable firms are operating which extend their activities into various markets around the globe (Sigfusson, Arnason, and Morrissey, 2013) The Icelandic quota fisheries management system has also increased profitability (Arnason and Agnarsson, 2005) and led to a sustainable fisheries management.

Icelandic marine-technology firms have been highly innovative and a number of Iceland's marine-technology firms have gained substantial niche worldwide positions in biotechnology, green ocean technology, fisheries technology, seafood processing and software (Arnason and Sigfusson, 2012). This study observes marine technology entrepreneurs in the marine/seafood industry. The research question is: How do marine technology entrepreneurs in Iceland build their business relationship networks through weak and strong ties and does a formation of an industry cluster affect their relationship networks.

The paper is divided into four sections. First reviews the relevant literature which frames the investigation. Second, describes the methodology in this research. Third, discusses the case studies. Four, introduces a conceptual model of relationships. Finally, the paper ends with conclusion and implications.

\section{Networks and Weak and Strong Ties}

Field (2003) states that the central thesis of social capital theory is "relationships matter". These relationships are knitted in social networks which are a valuable asset enabling people to commit themselves to each other. Network relationships generate social capital (Arenius, 2002; Autio, 2005). A sense of belonging and the concrete experience of social networks (and the relationships of trust and tolerance that can be involved) can, it is argued, bring great benefits to people (Powell \& Grodal, 2005).

Business actors require resources such as capital, skills and labor to start or expand their business activities. Some of these resources they hold themselves but they access other resources by utilizing their contacts which help them 
getting things done. Social capital is the outcome of successful contacts and is the key component of entrepreneurial networks (Burt, 1992). Maurer and Ebers (2006) define social capital as "an asset available to individual or collective actors that draws on these actors' positions in a social network and/or the content of these actors' social relations" (p. 262).

Networks are important in identifying opportunities (Johanson \& Vahlne, 2006). We use the term network in line with Chetty and Agndal (2007) who refer to interconnected relationships between different agents. Since we are focusing on entrepreneurs, we define network relationships as dyadic relationships between two agents, particularly through social relationships. The degree to which individuals are enmeshed in the network is referred to as embeddedness (Granovetter, 1985). The embeddedness, or level of strong and weak ties in networks (sometimes referred to as weak and strong relationships), can enhance the ability of entrepreneurs to acquire resources (Batjargal, 2003). Granovetter (1973) suggests that the strength of the tie is a "combination of the amount of time, the emotional intensity, the intimacy and the reciprocal services that characterize the tie" (p.1361). These ties are either weak or strong. Strong network ties have high levels of social relationship or personal interaction with high frequency (Granovetter, 1985). The strong network ties mean that members are motivated to be of assistance and protect actors in insecure positions (Hite \& Hesterly, 2001). Weak ties, however, are not as heavily based on personal interaction among members of the network but may provide strategic advantage in terms of resource availability (Granovetter, 1973). Weak ties act as "local bridges" to parts of the network which would otherwise be disconnected (Krackhardt, 1992) and weak ties offer opportunities (Burt, 1992).

The importance of network relationships in internationalization of firms (Johanson \& Vahlne, 1977), relationship perspective research (Dyer \& Singh, 1998; Madhok, 1995), network research (Larson \& Starr, 1993) and international entrepreneurship research (Oviatt \& McDougall, 2005; Coviello, 2006) is well recognised. Network relationships between firms or individuals are especially critical for the internationalization of small high-technology firms (Coviello, 2006).

Being linked to a network is not the only issue; one must be in a position to do something within that network. A relationship with someone who has a strong social position and reputation in another territory can help build trust, awareness and visibility in that territory (Powell, Kogut, \& Smith-Doerr, 1996). A relationship that is centrally located within the networks of a territory will be more than one that is peripherally attached. A number of sources of this strength of embeddedness within networks have been noted (Hite, 2003). Structural embeddedness comes from the overlap of social relations, cognitive embeddedness reflects how much people share mental models and ways of thinking with others, and cultural embeddedness reflects their sharing of beliefs and values (Zukin \& DiMaggio, 1990).

\section{Industry Clusters}

This study focuses on network relationships as an initial tool for further developing of an industry cluster. Such analysis is in line with Sforzi (2002) and Becattini (2001) analyzing a number of clusters formed in the rural areas of Italy. The success of these clusters is explained by the social relations among community members. Through clusters, networks of contacts emerge between individuals across firm boundaries, and act as channels of knowledge flow (Dahl and Pedersen, 2004) which give firms located in clusters certain advantages regarding innovative performance (Saxenian, 1994).

As the relationship network of marine-technology entrepreneurs are especially studied in relation to a formation of an industry cluster, the theoretical foundation of this study is a combination of network- and cluster theory. Porter (1990), one of the principal pioneers of cluster research in the world, defines clusters in economic sectors as:

.... group of related companies, suppliers, service providers, companies in related sectors and public bodies ... in specialised fields that compete among themselves but also work together.

Cluster analysis has been used to explain the development of industries and business in specific regions. It has subsequently been used to explain the growth and development of towns, cities and even nations.

Delgado, Porter and Stern (2012) find that new regional industries emerge where there is a strong cluster environment and suggest that the presence of strong clusters in a region enhances growth opportunities in other industries and clusters. Sigfusson, Arnason and Morrissey (2013) find that through a base industry in Iceland, fisheries, a wide range of companies have gradually developed to service the sector and through these inter linkages, the fisheries sector and its related operations can be viewed as an industry cluster.

The developmental history is typically as follows: a certain region has, or there arises, favourable economic conditions due to the progress of the economy and/or technology. These conditions are often based on natural 
resources, although this is not a prerequisite. Individual companies begin operations in the area and form a base industry. A group of companies in related fields then form around this base industry. These companies both serve the base industry and receive various forms of support from it. They are also linked to each other in numerous ways and support each other through, e.g. the development of human resources, technology and technological equipment that is of use to them all. The companies, moreover, circulate assets among themselves through transactions and transfers of employees, and at the same time, create a demand for further services and infrastructure that is also useful to all. Cluster analysis involves a detailed examination of such developments and the manner in which the cluster's industries are connected and the arrangement of their manufacturing processes.

There has been considerable international interest as regards research into clusters in business sectors and their role in the development of companies and business sectors. Many of the countries around the North Atlantic Ocean have issued detailed analysis and policy formulations on clusters connected to the ocean. Iceland cluster formulation in fisheries has been analysed (Sigfusson, Arnason and Morrissey, 2013). Ireland has set itself the goal of becoming, by 2020, an international centre for specialisation and research into ocean related technology (Marine Institute, 2007). And, Newfoundland has introduced an ocean technology cluster, Ocean's Advance (oceancesadvance.net). Cluster research, therefore, has been carried out in nearly all the countries that have a North-Atlantic shoreline.

\section{Methods and Early Findings}

This research is explorative and rooted in Eisenhardt's (1989) interpretative methodology, which allows theory and data to interact. The research began as a $\mathrm{PhD}$ research focusing on relationship networks of software entrepreneurs. In the preliminary interviews conducted in 2010, the researcher interviewed 5 software entrepreneurs. Two of them were involved with marine technology. What emerged from these preliminary interviews was an indication of a different relationship networks between the marine technology entrepreneurs and the others. The two marine technology entrepreneurs had a smaller relationship network than the others even though all of them were actively seeking international business opportunities and had similar educational background.

In January 2011, the researcher gathered a group of 20 marine-technology entrepreneurs to discuss their relationships and whether their group could gain from further relationships. This group has never had a formal platform to meet. One third of these firms are members of the Federation of Industry but the Federation had not formed any special group for the marine technology firms. The discussions from this meeting were recorded and transcribed. For the researcher, the interest to study further the relationship network of the marine technology entrepreneurs was further enhanced at this meeting mainly due to the fact that this meeting started by revealing that these entrepreneurs rarely knew each other. They indicated they had met at the Fisheries Exhibition in Brussels (which is held yearly) but further relationships were rare.

Our next step would be to examine the relationship networks of individual marine-technology entrepreneurs. For this we needed to observe as thoroughly as possible the context of the relations of the entrepreneurs and the nature of these relationships. The method used involves a case study approach formalised by Eisenhardt (1989) and action research involving a process of actively participating in an organization change situation whilst conducting research (Lewin, 1944).

This study focuses on marine-technology entrepreneurs owning small firms (with fewer than 10 employees at the time of the research). The entrepreneurs are all founder-owners (or part owners) responsible for general management. Such informants are considered appropriate as they typically have knowledge of the venture's various relationships (McCartan-Quinn \& Carson, 2003).

Case study methods using interview and archival data can uncover contextual or complex multivariate conditions well, so are particularly appropriate for exploring the personal networks of international entrepreneurs in emerging entrepreneurial firms (Eisenhardt, 1989; Eisenhardt and Graebner, 2007; Yin, 2003). To further understand the value of the relationship formation within a cluster, the entrepreneurs were interviewed again 19 months later. At that time a new industry cluster had been formed about six months earlier. This gave the researcher an opportunity to study the possible effects a cluster formation has on relationships among entrepreneurs.

The research design sought credibility through triangulation at group meetings, multiple cases and two interviews over time for each case. The interview schedule was designed to explore and unravel the issues and the thinking of the interviewees themselves in as non-directive a way as possible (Harris, 2000). The following are the eight detailed stages of the research.

\subsection{Stage I: Case entrepreneur identification, checking and follow-up}

The marine-technology sector in Iceland has several internationally leading players. The largest of these firms is 
Marel which is a major supplier of food processing machinery, with 3500 employees worldwide. Other leading firms have a strong niche position in fishing gear, plastic containers etc. These firms have 50-100 employees in Iceland. The remainder is a group of 35 firms, with an average of ten employees. The group of these 35 firms became the group which the researcher would focus on.

To meet the study's research aims, the selection of cases was purposeful (Davidsson, 2008). We identified marine technology entrepreneurs who all own and operate small marine technology firms. All originated from Iceland, an open economy with many marine technology firms. Access and agreement to participate was solicited. Reviewing and checking procedures resulted in 8 entrepreneurs that were eligible within the criteria frame and who agreed to participate, a number that Eisenhardt (1989) suggests is likely to be sufficient to lead to data saturation in qualitative case analysis. .

\subsection{Stage II: Panel discussion with 20 entrepreneurs}

After the preliminary interviews, the researcher's intention was to reflect on his initial findings from the preliminary interviews with a larger group of marine-technology entrepreneurs. 20 entrepreneurs were invited to a meeting which took place in early 2011. This participant observation was intended to inform the researcher about how small marine-technology entrepreneurs were connected, how often they met etc.

\subsection{Stage III: Interviews}

Our informants are the entrepreneurial owners of the firms. The first interviews ranged from 100 minutes to 120 minutes in length, and were conducted in the Icelandic language. To ensure that a priori research notions were not inserted into the participants' responses, no formal discussion or requests for comments or ideas were made before the interviews. For the purpose of name generating and name interpreting a number of questions were posed which provided some structure to the interviews, in the three-step approach commonly employed to collect personal network data (Matzat \& Snijders, 2009). First, to obtain a list of the most important relationships, each participant was asked to list the relationships that were most important to them in the business. Then a series of questions, called name interpreters, identified characteristics of the individuals involved and the relationships that they have.

Third, an open discussion to elicit further data about the nature of the relationships between the entrepreneur and the individuals named, and how that affected their international venturing. This was pursued in as open and non-directive way as possible (Harris, 2000). This led to a list of relationships and discursive data that would describe the embeddedness, and strength and value of those relationships. Further, we asked questions to gain a perspective of the overall interests and orientations of the entrepreneurs, in case this also relevant to the kind of relations they had developed.

\subsection{Stage IV: Forming of an industry cluster}

After the panel discussion at stage II, the researcher decided to initiate a formal cluster project at the University of Iceland with the aim to establish a formal industry cluster. In May 2011, the Iceland Ocean Cluster was formally announced with 20 members.

\subsection{Stage V: Second interview}

The second interviews lasted on average 60 minutes and were conducted 19 months after the first interview. The time difference allowed the researcher to explore possible changes over the 19 months time interval such as the relationship network of the entrepreneur and the effects on the relationships due to the formation of the Iceland Ocean Cluster

\subsection{Stage VI: Data Analysis}

Data analysis then involved interpretation of the case data within the paradigms of understanding that, a priori, appeared to have relevance. The analysis here involved identification of the aspects of the business behaviour that appeared to be adequately explained by the theoretical constructs, and identification of aspects of the business behaviour that was not. Areas of behaviour that were not well understood were collated and associated with other frameworks that appeared to have value.

The coding was adaptive, reflecting ideas that emerged inductively from the descriptions themselves. The analysis of each entrepreneur was then fed back to the entrepreneurs to confirm that there had not been misinterpretation of the business behaviour observed. 


\section{Findings}

We now present findings regarding the relationships of the participating entrepreneurs, how they perceived those relationships and how they developed them. The findings will be presented in three sections 1) the description of the initial network of relationships of participating entrepreneurs, 2) the effects of the formation of a cluster on the relationships of the entrepreneurs and finally, 3 ) introducing a conceptual model of relationships.

\subsection{The Initial Network of Relationships}

The marine-technology entrepreneurs were able, relatively easily, to obtain knowledge and early revenues from strong domestically embedded marine industry relationships. These people quickly saw value in the knowledge and the skills of the entrepreneurs and were sufficiently confident to invest in it. It was natural therefore for the marine-technology entrepreneurs to focus on these domestic relationships, who were as one entrepreneur noted

.. in our homegarden and we could get in touch with them right here.

This led to a natural development of these firms from initialization to early commercialization in which the entrepreneurs could rely on their domestic relationships to help them. Still most of the entrepreneurs had from initiation planned for their products to reach a global market.

The relationship network of the marine-technology entrepreneurs began to develop in the way highlighted by Coviello (2006). They had already commercialized through domestically embedded relationships that being local, were easily developed. They then sought globally embedded relationships, but this was a new and unfamiliar task for these entrepreneurs. Some of the domestically embedded relationships, however, were part of global networks, and could fulfill the role of 'introducers' in the way that Johanson \& Mattsson (1988) suggest. For example,

We had high hopes that the part ownership of the Icelandic fish processing plant by a Belgian firm would push us further into the European market with our technology.

Most research (e.g. Coviello, 2006) indicates that at early stages, most entrepreneurs would seek to rely on strong trust and knowledge based relationships, people with the ability to add directly to the competitive advantage of the new venture and/or introduce, possibly develop potential customer relationships. All the marine-technology entrepreneurs had developed their products in relationships with domestic individual firms that pre-dated the inception of the firms, with people known to them very well. The effect of this in the early days was profound:

I got a kick-start as (Icelandic firm) bought my concept and idea from day one

This early establishment of strong relationships with local firms at the initial stage of the venture considerably benefited the establishment of their firms and their early development. First, it helped the firms to attract other resources. These relationships presented possibilities for developing valuable inter-personal relationships in other sectors and territories that could become stronger over time. But most important, the focus at this stage was building relations with further potential business clients, irrespective of territory, which for the marine-technology entrepreneurs meant

... finding the customer who is willing to try the product

The strong relationships the marine-technology entrepreneurs established early presented them with a ready source of clients that could be further developed. Their proximity to the marine industry had led to a tradition of cooperation between the two sectors that helped the entrepreneurs to generate a revenue stream from the earliest days.

My background is in fisheries and my family grew up in a small fishing village. I know this business. So after returning from studying software engineering it was obvious for me to consider developing technology business opportunities in this field.

All the entrepreneurs worked hard to develop new relationships at the initial stages and it was easy for the marine-technology entrepreneurs to develop a relationship portfolio with strong relationships. First, they started with a good array of strong domestic relationships. These strong ties assisted them in some cases to go global:

A part owner of the second Icelandic processing firm we worked with is a foreign investor. Our first contract abroad was with these guys and it was realized through the Icelandic firm.

Second, having a proven product that was selling domestically, made it much easier to generate interest, especially at trade fairs which could be used to good effect. 
Third, they inherited a worldwide strategic network identity based on Icelandic prominence in the marine industries generally. Several discussed the benefits gained from the domestic track record and having strong Icelandic specialists in fisheries and seafood. As Anderson, Håkansson, and Johanson (1994) note:

.. when a firm perceives that it has a strong strategic network identity, brokering, negotiation, and selection advantages can then be parlayed into competitive advantage for the firm. (P. 3).

We see here a strong network identity representing 'an important strategic capability that enhances the value of a firm's relational assets' (Bonner, Kim \& Cavusgil, 2003: 1378), which would help them to form new relationships internationally, which they typically did through participation in trade shows.

The thing is Iceland is known in the seafood business around the world as being in the forefront of quality.

I am known in the industry as bringing new ideas - I came from a seafood country, people bought my ideas and they worked well. They trusted that I would not run away from them

But though forming relationships was relatively easy for the marine-technology entrepreneurs it may have led them to be less strategic in their relationship network building. There were three reasons for this. First, even though the entrepreneur's domestic relationships often led to initial exports, they rarely led to strong globally embedded relationships. The domestic client industry was inwardly focused, so maintaining strong relations with domestic relationships did not greatly help them to develop a strong international network.

Second, they formed and invested in stronger relationships. When the entrepreneurs began their exports, they rarely worked with their weak relationships and were uncomfortable about changing their way of working to do so. They were used to working with strong relationships, and they all sought to work closely and not remotely with any contact that were made. One participant illustrated the approach well:

I have a Scottish client whom I met at a trade show years ago. We have developed a very good relationship which has led to further product development.

Third, the marine-technology entrepreneurs had a relatively protective attitude towards relationships. They had strong network relationships with a few buyer companies, in which they had invested time, and commitment and had collected a number of obligations. It was natural for them to protect their valuable assets:

There is a lot of duplication going on.

An employee of mine left a couple of years ago ... with my invention, just changing the look but using similar ideas and software.

\subsection{An Industry Cluster and Relationship Networks}

In December 2012, the eight marine-technology entrepreneurs were interviewed. These second interviews lasted on average 60 minutes. This interview asked more detailed questions about some of the relationships if they were not clear from the first interview.

At the initiation of the Iceland Ocean Cluster, a group of 35 marine-technology entrepreneurs were all invited for several meetings of the Cluster. These meetings were held with two months interval in the period of March 2011 until January 2013. Of the 35 entrepreneurs, 24 of them were active in the group and 12-18 met at each meeting. The meeting platform was based on similar strategy as presented by Ffowcs-Williams, I. (2012) and in the evaluation of three Swedish clusters (Cooke, P., Eickelpasch, A., and Ffowcs-Williams, I., 2010). The strategy regarding the initial steps of industry clusters was based on the aim of establishing a momentum and preparing at an early stage certain low hanging fruits for the group, some projects which could show benefits for the members within a relatively short period of time.

The main emphasis of the meetings was however to get the marine technology entrepreneurs to meet and discuss their interest and possible cooperation. The initial meetings revealed that many of the marine technology-entrepreneurs had never met. Even though these entrepreneurs were many servicing similar clients (but often with very different products) they had not made significant effort to cooperate. One marine-technology entrepreneur responded this way:

If a need to cooperate I will just pick up the phone and make a call.

When asked how much he had done that in the past 12 months he reflected

I don't recall. I have not had any particular needs to do so in some time. 
At all the meetings which the researcher participated in, detailed minutes were made. Coding the minutes of the meeting indicated strongly the interest of the group to meet and talk and collaborate. At the first meetings, a significant part of the meeting time was used to get them to know each other's business and there was a clear interest to

Do something together

The reflection from the participants was

I did not know that we were so many.

I think it could be an idea for us to see if we can cooperate at trade shows. Most of us are small and it takes a lot of efforts for my small operation to participate as a stand-alone in a trade show.

At meeting 3 and 4, the participants met at the sites of two of the participant's operations. This gave the group a good opportunity to start building knowledge about the activities of each other and to build trust. The ideas for cooperation had developed:

I see various co-op possibilities regarding environmental issues, marketing, technology exchange, communication etc.

We might consider cooperating regarding the development of small boats where Icelandic marine-technology firms have had a comptetitive advantage

Still, the underlying interest of the group was to „broaden the horizon of the group“, and „get us to meet more“, etc.

As indicated in the analysis of the first interviews, the entrepreneurs were not very strategic in their relationship network building. Their initial strong relationships had helped them establish their business but the domestic client industry was inwardly focused and the entrepreneurs were less used to working with weak relationships. They had become used to working with strong relationships and felt more comfortable with such relationships. The interviews indicated strongly that the entrepreneurs had all participated in the cluster activity. They did not indicate that over this period the list of strong ties had changed significantly (three new strong ties identified among the participants) but the list of weak ties had become longer and more of marine-technology entrepreneurs in Iceland were mentioned. The participants indicated that the cluster activity had resulted in various new formations of relationships.

I have already opened relations with two firms in the cluster regarding the development of our products

We received a good contact at the cluster meeting for a Russian company and we followed the lead which led to a sales agreement.

The cluster activity was also mentioned as a tool to increase the interest for the industry as a whole

The cluster has made more people aware of our business which has in itself been very positive for us. But generally speaking we are dealing with the same clients as before.

The interviewed indicated not only that their relationship network had expanded as they were participating in a new group but also that they were focusing more on weak relationships than previously.

I realized I needed to expand my network. I am now looking for marketing people in Europe.

This was partly due to the fact that in the industry cluster some of the largest marine-technology firms presented their marketing strategy and the development of this strategy. It was evident that the expansion strategy of the larger marine-technology firms was based mainly on weak ties and the development of these ties into strong ties by mutual service agreements with first time clients etc. Here, the industry cluster assisted in benchmarking for the marine-technology entrepreneurs how the larger firms had expanded. This leads to the questions whether the change in the relationship network strategy of the marine-technology entrepreneurs due to the participation in the industry cluster, therefore only benefitted the marine-technology entrepreneurs but not the larger technology firms? The interviews focused on the small firms so this research is not able to answer in any depth that question. An indication about mutual benefits for both large and small members of the cluster may have been indicated in the interviews when the marine-technology entrepreneurs talked about more frequent business meetings with the larger firms as a result of the industry cluster.

We have had much more talk with the $\mathrm{X}$ (medium sized marine-technology firm) as a result of our participation in the cluster. The dialogue is already there and I think they see a chance in using us for specialty manufacturing while they will focus on standardized products. 
We have met with one of the former managers of $Z$ (large food-technology firm) and he has emphasized the importance for me to not focus on my particular machinery for fish processing but on complete solutions. But to do so I need to build a larger group of collaborators.

After the first five meetings of the marine-technology entrepreneurs, a project was initiated which the researcher has followed closely. This project focuses on collaboration between 10 marine-technology firms (three relatively large and nine small firms) in selling green marine technology. This is an initiative which came from the entrepreneurs themselves and can be categorized as one of the low hanging fruits which the entrepreneurs are seeking through the cluster cooperation. It remains to be seen if this activity results in more sales or further cooperation among the marine-technology entrepreneurs. The project, however, shows an interest on behalf of the marine-technology entrepreneurs to increase cooperation. It is too early to tell if the project will lead to building of strong ties among the participants. As one participant indicated

This project will not necessarily lead us to cooperating on an R\&D level but I am sure it can lead to further cooperation in sales and marketing.

Even at the early stage of the cluster formation, the first indication is that the marine-technology entrepreneurs have increased their network of weak ties. These ties have been used to get contacts domestically and abroad but at this early level it is hard to see if these ties will have significant effect on the business of the marine technology entrepreneurs. It was, however, a strong indication in the second interviews that the formation of the cluster had the potential to build bridges.

We have never seen ourselves as a part of any particular group. It seems as we have never been "a favorite industry" in Iceland like the IT industry etc. The introduction of our new cluster gave us the opportunity to present our business which has helped us.

Another marine technology indicated strongly that the cluster had affected their relationship network, both regarding weak and strong ties.

We have already started discussions with another marine-technology firm in the cluster regarding a mutual development project where we will combine our efforts. In the coming months we will display a technology combining our technology and theirs. I think it will be surely good for both of us.

We see the potential in the increased number of weak ties through the formation of the cluster, mainly in opening further sales and marketing of the marine technology entrepreneurs.

We are creating a new marketing programme which combines our technology with another company. We are not sharing our patents but we can easily sell more by cooperating at trade shows.

The weakness of many of the small marine-technology firms lies in the inability to actively seek different markets (due to their size). The increased weak ties among the marine-technology entrepreneurs can lead to further bridging to different markets where for instance a marine-technology entrepreneur in cooling technology will assist a marine-technology entrepreneur in fish cutting to establish contacts and vice versa. The initial sharing may only be in sharing business contacts or opening a sales meeting as in one case mentioned

A European fisherman visited a marine-technology in the cluster and as they began talking he mentioned he wanted to meet some interesting firms in fish transportation and storing technology. I mentioned the name of X (a marine technology company) which we had been meeting at the cluster and they visited them.

Other interviews indicated the different approach which the marine technology entrepreneurs were taking after joining the cluster regarding their network relationships

I am meeting a lot of investors and presenting my business case. I have not done this before but I think I need to do this if I am to become anything more than a one man show.

As the cluster is still in its infancy, only three cases being studied indicated that marine technology entrepreneurs had build a new strong relationship through the cluster. Strong ties take time to develop. Creating and nurturing weak relationships was initially not the strategy seen in the business model of the marine technology entrepreneurs. But as they became more involved in the industry cluster work they emphasised more on nurturing weak relationships while they still cherished strong relationships but realised they provide few new opportunities and are rare and hard to develop. 


\subsection{Introducing A Conceptual Model of Relationships}

The model in Figure 1 presents a suggested view on conceptualizing relationships of marine-technology entrepreneurs in an industry cluster. In this model, we partly address Slotte-Kock and Coviello's (2009) call for further examination of their "general model" on network development. Their model consists of the following components, "what develops?", "how and why does the network develop?", and "what occurs over time?" This model develops further the issue of how and why the network develops and the variations in ties which is a part of Slotte Kock and Coviello's "what develops". The model focuses on the nature of the relationship formation which lead to discovery or enactment. The model shows the relationship opportunities in the network of the entrepreneur as an outcome of the characteristics of the entrepreneur (which might be described as the internal factor). The focus on the entrepreneurs and their background is therefore an important part of the model. But, even though analysis at the firm level is useful for giving the theorist a sense of the bigger picture, "it does so at the risk of overlooking important information exchanges that take place at the level of the entrepreneur" (Ellis, 2011, p.102). So, the analysis of entrepreneurs' social networks offers a significant conceptual advantage (Ellis, 2011) over the analysis of inter-firm networks. The model also emphasizes that industry cluster affects relationship networks. The model therefore allows for both exogenous and endogenous influences in relationship networks of international entrepreneurs.

In Part A of the model certain capabilities of the entrepreneurs are observed which may affect their relationship networks. The characteristics of the entrepreneur influence the model as his/her experience has affected the relationship network and therefore opportunities (Paul-Wiedersheim, Olson \& Welch, 1978). The model recognizes different entrepreneurs and their different levels of relationship skills. This approach is in line with Sigfusson and Chetty (2012) study on software entrepreneur's relationship capabilities and Ellis (2011) emphasis on why some agents manage social and business networks better than others?

Entrepreneur's Capability

\begin{tabular}{c} 
High non-reduntant \\
relationship skills \\
$\begin{array}{c}\text { Low non-reduntant } \\
\text { relationship skills }\end{array}$ \\
\hline
\end{tabular}

A
Industry Cluster

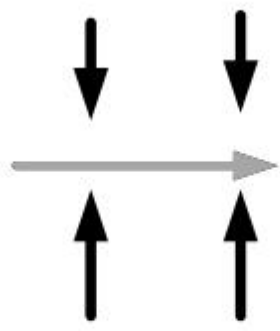

Portfolio of Relationships

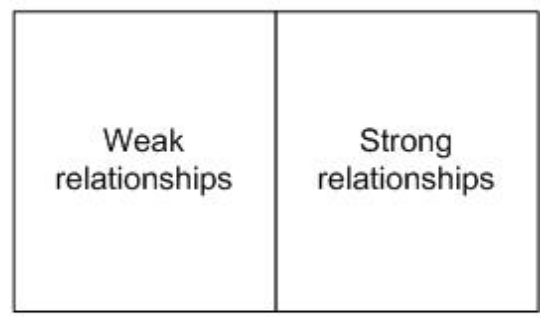

In part B of Figure 1 we note the effects of the industry cluster, on relationships which can provide partial explanation of the entrepreneur's development. Aldrich (1999) argues that the entrepreneurial process takes on meaning only in the context of the broader social context. Using this model, we show that industry cluster presence affects the "process through which ties are selected for entrepreneurship" (Jack, 2010: 133).

The relationship resources in part $\mathrm{C}$ shows the portfolio of relationships where factors such as the entrepreneur's capability and exogenous factors such as industry cluster, are important determinants of the entrepreneur's portfolio. The notion of network as a set of portfolios was addressed by Ozcan and Eisenhardt (2009) who emphasized that ties are formed "in the context of building portfolios" (p.246). The different dynamic capabilities for relationship portfolio development have considerable influence on the entrepreneurial development.

All entrepreneurs, irrespective of their industry, create personal relationships to develop their ventures. The model in Figure 1 describes the dynamics between relationship skills and industry clusters and how the interaction between them can affect the portfolio of relationships. We suggest that the existence of industry clusters should be addressed by researchers when observing technology entrepreneurs in different industries.

\section{Conclusions}

This study has found that marine-technology entrepreneurs focus mainly on strong relationships in their business ventures. Although the marine-technology entrepreneurs appear to value weak relationships less, we can see that 
since they became actively involved with the industry cluster work, their patterns of relationship network changed in the way that they were more actively involved with number of weak relationships and developed their skills in nurturing weak relationships.

The industry cluster, a formal relationship network, assists the entrepreneurs to develop network relationships. This is not only true for the relationships within the cluster. The participants seem to develop knowledge in developing their network and manage their network as they become more aware of network capabilities through the industry cluster work, witnessing the network capabilities of larger firms and how they establish and manage relationship portfolios. This is in line with Dahl and Pedersen (2004) who find engineers to acquire valuable knowledge through industrial cluster networks. The marine-technology entrepreneurs realise that the individual cost of any of the weak relationships is low, but the large numbers allow many opportunities to be spotted, a pattern of large numbers of informal weak relationships beneath the formal relationships which has been seen in the life science businesses (Powell et al., 1996). This is particularly important as the marine-technology entrepreneurs plan for global marketing of their products. In line with Chetty (2004), we find internationalisation to contribute to the development of the cluster rather than the reverse. The interest to internationalise led the entrepreneurs to appreciate the benefits of collaborating, initially based on weak relationships, with each other as they began expanding globally.

The question here is obviously will these increased weak relationships create some business or are they mainly relationships which have no significant effect on the businesses? As indicated by Granovetter (1973), weak ties interaction among members of the network may provide strategic advantage in terms of resource availability and they may provide opportunities (Burt, 1992).

In this study the difference which the participants note with the formation of an industry cluster lies mainly in the increased social relations and trust among the members of the industry cluster. The social capital of the cluster seems to have had a positive impact in the development of marine technology enterprises as more relationships have been created and the entrepreneurs see more opportunities.

The key implications of this study on relationships and networks for the development of industry clusters are

1) Industry clusters need to implement mentoring programmes, where experienced networkers transfer knowledge to new firms regarding network relationships.

2) The role of an industry cluster should be to increase trust and encourage strong relationships. These relationships are hard to develop and therefore the focus of the cluster should be on developing the skills of the participants to nurture and develop their weak relationships.

3) Social capital, often overlooked in the industry cluster analysis, is very important in facilitating collaboration in industry clusters. Rather than focusing on more macro aspects of clusters, involving Government and other large institutions, often seen as key to the success of an industry cluster, clusters might consider initially focusing solely on building relationships between entrepreneurs.

Whether based on weak or strong relationships, networks in industrial clusters can provide opportunities and are especially important in the development of the marine technology entrepreneur. Entrepreneurs should consider how they could strategically build their networks, through the industry cluster, both with weak and strong relationships, to access a diverse array of skill sets and by that create bridging relationships for their ventures.

We have attempted to contribute to the network theory and the theory of industry clusters in two ways. First, we have identified social relationships as important tools in the initial work of the industry clusters. Social capital, often overlooked in the industry cluster analysis, seems to play a very important role in increasing the strength of the industry cluster as a mediator of opportunities and trust building. Second, by combining network and cluster theories in studying the development of marine-technology ventures within an emerging industry cluster, this study contributes to network and cluster theories by attempting to model the important links between them when analysing the relationship networks of marine technology entrepreneurs.

One limitation of this paper is that we focus solely on marine technology entrepreneurs. Qualitative studies could be conducted in other industry settings to make analytical generalizations. Future studies could observe other industries and the effects of cluster formations on the relationship networks of entrepreneurs,

\section{References}

Arenius P. (2002.) Creation of firm-level social capital, its exploitation and the process of early internationalisation. Helsinki Finland: Helsinki University of Technology.

Arnason, R. \& Agnarsson, S. (2005). Sjávarútvegur sem grunnatvinnuvegur á Íslandi. Reykjavík. 
Arnason, R., \& Sigfusson, T. (2011). Umfang og horfur í tæknifyrirtækjum í sjávarklasanum. Frumathugun á fjölda tæknifyrirtækja í sjávarklasanum,bróun og horfur. Íslenski sjávarklasinn,Reykjavík.

Arnason, R., \& Sigfusson, T. (2012). Pýðing sjávarklasans í íslensku efnahagslífi. Islandsbanki, Reykjavík.

Autio A. (2005). Creative tension: The significance of Ben Oviatt's and Patricia McDougall's article 'toward a theory of international new ventures'. Journal of International Business Studies, 36(1):9-19. http://dx.doi.org/10.1057/palgrave.jibs.8400117

Batjargal, B. (2003). Social capital and entrepreneurial performance in Russia: A longitudinal study. Organisation Studies, 24(4), 535-556. http://dx.doi.org/10.1177/0170840603024004002

Becattini, G. (2001). From Marshall's to the „„Italian industrial districts". A brief critical reconstruction. [Online] Available: 685/original/becattini_marshall.pdf

Burt, Ronald S. (1992). Structural holes: The social structure of competition. Cambridge, MA: Harvard University Press.

Chetty S. (2004). On the crest of a wave: the New Zealand boat-building cluster. International Journal of Entrepreneurship and Small Business. 1(3) 313-329. http://dx.doi.org/10.1504/IJESB.2004.005662

Chetty, S. \& Agndal, H. (2007). Social capital and its influence on changes in internationalization mode among SMEs. Journal of International Marketing, 15(1): 1-29. http://dx.doi.org/10.1509/jimk.15.1.001

Cooke, P., Eickelpash, A. \& Ffowcs-Williams, I. (2010). From low hanging fruit to strategic growth. International evaluation of Robotdalen, Skåne Food Innovation Network and Uppsala BIO. Vinnova Report.

Coviello, N. E. (2006). The network dynamics of international new ventures, Journal of International Business Studies, 37, 713-731

Dahl, M.S. \& Pedersen, C.O.R. (2004). Knowledge flows through informal contacts in industrial clusters: myth or reality? Research Policy. Vol. 33(10): 1673-1686. http://dx.doi.org/10.1016/j.respol.2004.10.004

Delgado, M., Porter, M.E., \& Stern, S. (2012). Clusters Convergence and Economic Performance. Working Paper 18250. http://www.nber.org/papers/w18250. National Bureau Economic Research, Cambridge, July 2012. http://dx.doi.org/10.3386/w18250

Dyer J. H. \& Singh H., (1998). The relational view: Cooperative strategy and sources of interorganisational competitive advantage, Academy of Management Review, 23(4), 660-79.

Eisenhardt, K. M. (1989). Building theories from case study research, Academy of Management Review, 14/4, 532-550.

Ellis, P. (2011). Social ties and international entrepreneurship: Opportunities and constraints affecting firm internationalisation. Journal of International Business Studies, 42( 1): 99-127. http://dx.doi.org/10.1057/jibs.2010.20

Freeman, S. \& Cavusgil, S. (2007). Towards a Typology of Commitment States among Managers of Born Global Firms: a study of accelerated internationalisation. Journal of International Marketing, 15 (4): 1-40. http://dx.doi.org/10.1509/jimk.15.4.1

Ffowcs-Williams, I. (2012). Cluster Development: The Go-To Handbook. Cluster navigators: New Zealand.

Field, J. (2003). Social Capital. London: Routledge.

Granovetter, M. (1985). Economic actions and social structure: The problem of embeddedness. American Journal of Sociology, 91: 481-510. http://dx.doi.org/10.1086/228311

Granovetter, M. (1973). The Strength of Weak Ties. American Journal of Sociology, 78 (6): 1360-1380. http://dx.doi.org/10.1086/225469

Harris, S. (2000). Reconciling positive and interpretative international management research: A native category approach. International Business Review, 9(5): 755-770. http://dx.doi.org/10.1016/S0969-5931(00)00030-5

Hite, J.M., \& Hesterly, W.S. (2001). The Evolution of Firm Networks: From Emergence to Early Growth of the Firm, Strategic Management Journal, 22(3), 275-286. http://dx.doi.org/10.1002/smj.156 
Johanson, J., \& Vahlne, J. E. (1977). The internationalisation process of the firm - A model of knowledge development and increasing market commitments', Journal of International Business Studies, 8/1: 23-32. http://dx.doi.org/10.1057/palgrave.jibs.8490676

Johanson, J. \& Vahlne, J-E. (2006). Commitment and opportunity development in the internationalisation process: A note on the Uppsala internationalisation process model. Management International Review, 46: 165-178. http://dx.doi.org/10.1007/s11575-006-0043-4

Krackhardt, D. (1992). The strength of strong ties: The importance of philos in organisations. In N. Nitin \& R. G. Eccles (Eds.). Networks and organisations: Structure, form, and action. Boston, MA.: Harvard Business School Press.

Larson, A. \& Starr, J. A. (1993). A network model of organization formation. Entrepreneurship Theory and Practice, 17(2): 5-15.

Marine Institute. (2007). Sea Change - A Marine Knowledge, Research and Innovation Strategy for Ireland 2007-2013. Ireland.

Madhok, A. (1995). Revisiting multinational firms' tolerance for joint ventures: a trust-based approach, Journal of International Business Studies. 26/1, 117-137. http://dx.doi.org/10.1057/palgrave.jibs.8490168

Matzat, U. \& Snijders, C. (2010). Does the online collection of ego-centered network data reduce data quality? An experimental comparison. Social Networks, 32:105-111. http://dx.doi.org/10.1016/j.socnet.2009.08.002

Maurer, I. \& Ebers. (2006). M. Dynamics of social capital and their performance implications: Lessons from biotechnology start-ups. Administrative Science Quarterly. 51(2): 262-292. http://dx.doi.org/10.2189/asqu.51.2.262

McCartan-Quinn, D. \& Carson, D. (2003). Issues Which Impact Upon Marketing in the Small Firm. Small Business Economics, 21: 201-213. http://dx.doi.org/10.1023/A:1025070107609

Oviatt, B.M. \& McDougall, P.P. (2005). Defining International Entrepreneurship and Modeling the Speed of Internationalisation, Entrepreneurship: Theory and Practice, 29: 537-554. http://dx.doi.org/10.1111/j.1540-6520.2005.00097.x

Ozcan, P. \& Eisenhardt, K. M. (2009). Origin of alliance portfolios: entrepreneurs, network strategies, and firm performance, Academy of Management Journal, 52, 2, 246-279. http://dx.doi.org/10.5465/AMJ.2009.37308021

Powell, W.W. \& Grodal, S. (2005). Networks of Innovators. In J. Fagerberg, D.C. Mowery, \& R.R. Nelson (Eds.) The Oxford Handbook of Innvovation. pp. 56-85.

Powell, W.W., Koput, K.W. \& Smith-Doerr, L. (1996). Interorganisational Collaboration and the Locus of Innovation: Networks of Learning in Biotechnology, Administrative Science Quarterly, 41, 116-145. http://dx.doi.org/10.2307/2393988

Porter, Michael E. (1990). The Competitive Advantage of Nation. Free Press, New York.

Saxenian, A. (1994). Regional Advantage: Culture and Competition in Silicon Valley and Route 128. Harvard Universoty Press, Cambridge, MA.

Sforzi, F. (2002). The industrial district and the nnew' Italian economic geography, European Planning Studies, vol. 10, no. 4, 2002. http://dx.doi.org/10.1080/09654310220130167

Sigfusson, T., Arnason, R., \& Morrissey, K. (2013). The economic importance of the Icelandic fisheries cluster-Understanding the role of fisheries in a small economy. Marine Policy. 39 (2013) 154-161. http://dx.doi.org/10.1016/j.marpol.2012.10.015

Sigfusson, T., \& Chetty, S. (2012). Building international entrepreneurial virtual networks in cyberspace. Journal of World Business (in press).

Slotte-Kock, S. \& Coviello, N. (2009). Entrepreneurship Research on network Processes: A Review and Ways $\begin{array}{llll}\text { Forward. Entrepreneurship Theory 34(1):31-57. } & \end{array}$ http://dx.doi.org/10.1111/j.1540-6520.2009.00311.x

Zukin, S., \& DiMaggio, P. (1990). Structures of capital: The social organization of the economy. New York: Cambridge University Press. 